\title{
PENGARUH MEDIA TANAM DAN PUPUK NPK 16:16:16 TERHADAP PERTUMBUHAN DAN PRODUKSI TANAMAN PAKIS SAYUR (Diplazium esculentum S.)
}

\section{The Effect of NPK Plants and Fertilizers 16:16:16 Toward Growth and Production of Vegetable Fern (Diplazium esculentum S.)}

\author{
Nescaya Suhendri, T. Rosmawaty dan Raisa Baharuddin \\ Fakultas Pertanian, Universitas Islam Riau \\ Jl. Kaharuddin Nasution 113, Pekanbaru 28284 Riau \\ (Diterima: Juli 2018; Disetujui: Agustus 2018)
}

\begin{abstract}
The purpose of this study was to determine the interactions and main effects of planting media and NPK 16:16:16 fertilizer on growth and production in vegetable ferns (Diplazium esculentum S.). The design used is a Factorial Complete Random Design. The first factor is the planting media of peat soil and mineral soil consists of 3 levels of treatment, namely: peat soil, mineral soil and a combination of 1: 1 peat and mineral soil while the second factor is NPK 16:16:16 fertilizer with 4 levels of treatment, namely: $0,0.3,0.6$ and $0.9 \mathrm{~g} /$ polybag so that 12 treatment combinations were obtained, with 3 replications, then a total of 36 experimental units were obtained. Each unit consists of 4 plants with 2 plants used as samples. Observation parameters consisted of the age of emergence of shoots, plant height, number of young leaves, economical wet weight and dry weight. The results showed that the interaction of planting media and NPK 16:16:16 fertilizers gave a real influence on the number of young leaves with the best treatment was the planting media of a combination of peat and mineral soil 1: 1 and $0.6 \mathrm{~g}$ NPK fertilizer 16:16:16 (M3N2). The main effect of the planting medium was evident on the parameters of plant height, number of young leaves, economic wet weight, and dry weight. The best treatment is found in a combination of peat and mineral media 1:1 (M3). The main effect of NPK 16:16:16 was significantly affected by the number of young leaves, economic wet weight and dry weight with the best treatment of $0.3 \mathrm{~g}(\mathrm{~N} 1)$.
\end{abstract}

Keywords: Growing media, NPK Fertilizer, Vegetable Fern

\begin{abstract}
ABSTRAK
Tujuan penelitian ini adalah untuk mengetahui interaksi dan pengaruh utama media tanam dan pupuk NPK 16:16:16 terhadap pertumbuhan dan produksi pada tanaman pakis sayur (Diplazium esculentum S.). Rancangan yang digunakan adalah Rancangan Acak Lengkap Faktorial. Faktor pertama adalah media tanam tanah gambut dan tanah mineral terdiri dari 3 taraf perlakuan, yaitu: tanah gambut, tanah mineral dan kombinasi tanah gambut dan mineral 1:1 sedangkan faktor kedua adalah pupuk NPK 16:16:16 dengan 4 taraf perlakuan, yaitu: 0, 0,3, 0,6 dan 0,9 g/polibag sehingga diperoleh 12 kombinasi perlakuan, dengan 3 kali ulangan, maka seluruhnya berjumlah 36 unit percobaan. Masing-masing unit terdiri dari 4 tanaman dengan 2 tanaman dijadikan sampel. Parameter pengamatan terdiri dari umur muncul tunas, tinggi tanaman, jumlah daun muda, berat basah ekonomis dan berat kering. Hasil penelitian menunjukkan bahwa interaksi media tanam dan pupuk NPK 16:16:16 memberikan pengaruh nyata terhadap jumlah daun muda dengan perlakuan terbaiknya adalah media tanam kombinasi tanah gambut dan mineral 1:1 dan 0,6 g pupuk NPK 16:16:16 (M3N2). Pengaruh utama media tanam nyata terhadap parameter tinggi tanaman, jumlah daun muda, berat basah ekonomis, dan berat kering. Perlakuan terbaik terdapat pada media kombinasi tanah gambut dan mineral 1:1 (M3). Pengaruh utama pupuk NPK 16:16:16 nyata terhadap jumlah daun muda, berat basah ekonomis dan berat kering dengan perlakuan terbaik $0,3 \mathrm{~g}(\mathrm{~N} 1)$.
\end{abstract}

Kata kunci: Media tanam, Pupuk NPK, Pakis Sayur 


\section{PENDAHULUAN}

Sayuran merupakan bagian pangan manusia yang berfungsi sebagai sumber vitamin, karbohidrat, dan mineral yang tidak dapat disubstitusikan dengan makanan pokok. Ada beberapa jenis sayuran asli suatu daerah yang telah banyak diusahakan dan dikonsumsi sejak zaman dahulu, sayuran introduksi yang telah berkembang lama dan dikenal masyarakat di suatu daerah tertentu disebut juga dengan sayuran indegenous (Putrasamedja, 2005).

Salah satu sayuran indigenous yang tumbuh liar di alam yang dimanfaatkan sebagai sayuran adalah pakis sayur. Banyak jenis pakis yang dikenal memiliki daun yang dapat dikonsumsi sebagai sayuran. Beberapa memiliki rasa yang sangat enak dan dijual sebagai makanan yang sangat lezat, terutama bagian daun mudanya yang masih menggulung. Namun, tidak semua jenis pakis dapat dikonsumsi, beberapa jenis pakis ada yang mengandung toksin yang tidak baik bagi tubuh manusia. (de Winter and Amoroso, 2003).

Tanaman pakis sayur umumnya hidup pada daerah yang mempunyai jenis tanah gambut. Tanah gambut merupakan tanah yang banyak mengandung bahan organik yang berasal dari akumulasi sisa-sisa vegetasi yang telah mengalami humifikasi tetapi belum mengalami mineralisasi. Gambut memiliki sifat kemasaman yang tinggi, ini dikarenakan asamasam organiknya yang tinggi, kejenuhan basa yang rendah dan miskin unsur hara baik makro maupun mikro.

Penambahan tanah mineral dalam media tanam gambut akan dapat mengurangi asam-asam organik yang dihasilkan selama proses dekomposisi yang bersifat racun bagi tanaman, yang dapat menghambat metabolisme tanaman dan berakibat terhadap penurunan pertumbuhan dan produktifitasnya, karena tanah mineral memiliki tingkat kemasaman yang lebih rendah dibandingkan tanah gambut dan kaya akan bahan polivenol.

Selain media tanam, dalam budidaya tanaman juga membutuhkan unsur hara sebagai bahan baku dalam proses metabolismenya. Unsur hara dapat diperoleh dari media tanam yang digunakan maupun berasal dari pupuk yang diberikan dari luar media untuk membantu penyediaan unsur hara di dalam media.
Tersedianya unsur hara makro di dalam media melalui pemupukan dapat meningkatkan pertumbuhan serta produksi tanaman.

Pupuk NPK 16:16:16 merupakan salah satu jenis pupuk yang dapat meningkatkan unsur hara makro yaitu $\mathrm{N}, \mathrm{P}$, dan $\mathrm{K}$ di dalam tanah. Pupuk tersebut mengandung unsur hara nitrogen, fosfor dan kalium dengan kadar masing-masing $16 \%$. Nitrogen dan fosfor dibutuhkan oleh tanaman untuk pertumbuhan dan perkembangan batang dan daun. Sedangkan kalium dibutuhkan dalam perkembangan akar tanaman. Dengan mengkombinasikan media tanam dan juga pupuk NPK 16:16:16 diharapkan mampu meningkatkan pertumbuhan dan juga produksi pakis sayur.

Tujuan dilakukannya penelitian ini adalah untuk mengetahui pengaruh interaksi media tanam dan pupuk NPK 16:16:16 terhadap pertumbuhan dan produksi tanaman pakis sayur.

\section{METODE PENELITIAN}

Penelitian ini telah dilaksanakan di Fakultas Pertanian Universitas Islam Riau. Waktu penelitian selama empat bulan dimulai dari Maret sampai dengan Juni 2018.

Bahan-bahan yang digunakan dalam penelitian ini adalah tanah gambut, tanah mineral, anakan pakis sayur, pupuk NPK Mutiara 16:16:16, gandasil D, paku, seng, cat hijau, kayu plang, plastik, karet gelang dan polibag. Adapun alat yang digunakan yaitu cangkul, parang, gergaji, garu, gunting setek, gembor, timbangan, martil, ember plastik, meteran,hand sprayer,penggaris dan alat-alat tulis.

Rancangan yang digunakan dalam penelitian ini adalah rancangan acak lengkap secara faktorial yang terdiri dari 2 faktor. Faktor pertama adalah dosis Media tanam (M) terdiri dari 3 taraf, sedangkan faktor kedua adalah pupuk NPK Mutiara 16:16:16 (N) yang terdiri dari 4 taraf sehingga terdapat 12 kombinasi perlakuan terdiri dari 3 ulangan. Faktor media tanam (M) adalah M1: Tanah gambut, M2 : Tanah mineral, M3: Kombinasi tanah gambut dan mineral 1:1. Faktor pupuk NPK 16:16:16 adalah N0: $0 \mathrm{~g} /$ polibag, N1: 0,3 g/polibag, N2: 0,6 g/polibag, N3: 0,9 g/polibag. 
Lahan penelitian diukur $4,8 \times 10,8$ meter atau seluas $51,84 \mathrm{~m}^{2}$, kemudian dibersihkan dari gulma serta sampah-sampah yang terdapat di lokasi penelitian. Selanjutnya tanah diratakan untuk mempermudah penyusunan polibag.Tanah yang digunakan dalam penelitian ini adalah tanah mineral jenis podsol yang diperoleh dari salah satu lahan di Kawasan Pasir Putih kedalaman 0-50 cm. Sedangkan tanah gambut diperoleh dari salah satu hutan di daerah Kabupaten Kampar. Jenis gambut yang digunakan adalah jenis gambut saprik. Tanah dipersiapkan sesuai dengan perlakuan yang telah ditentukan berdasarkan volume.

Pemasangan label dilakukan sebelum pengisian polibag. Label perlakuan dibuat menggunakan seng yang telah dicat sebelumnya dengan ukuran $10 \quad \mathrm{x} \quad 15 \mathrm{~cm}$ dan diberi penyangga dari kayu.Shading Net yang digunakan adalah jenis $65-75 \%$. Shading Net dipasang menggunakan penyangga yang terbuat dari kayu.

Bahan tanam untuk penelitian ini menggunakan anakan dari tanaman induk di habitat aslinya. Anakan diambil dipinggiran hutan daerah Kabupaten Pelalawan dengan kriteria anakan yaitu memiliki tangkai daun berjumlah \pm 5 buah, memiliki lingkar batang sebesar $\pm 6 \mathrm{~cm}$, berdaun hijau muda, dan tidak rusak. Anakan diambil dengan cara memilah dan memisahkan anakan dari induk, kemudian akar dan daunnya dipotong. Penanaman dilakukan dengan membuat lubang tanam di dalam polibag dengan kedalaman $\pm 5 \mathrm{~cm}$.Media tanam yang dipakai adalah tanah mineral dan tanah gambut.

Perlakuan media tanam dilakukan saat persiapan media tanam dan diberikan sesuai dengan jenis tanah yang telah ditetapkan.Pemberian perlakuan pupuk NPK
Mutiara 16:16:16 diberikan pada waktu tanam dengan ditabur di sekeliling tanaman sesuai dengan dosis yang ditetapkan.

Parameter yang diamati dalam penelitian ini adalah sebagai berikut : Umur muncul tunas (HST), tinggi tanaman $(\mathrm{cm})$, jumlah daun muda (Helai), berah basah ekonomis (g) dan berat kering $(\mathrm{g})$.

\section{HASIL DAN PEMBAHASAN}

\section{Umur Muncul Tunas (hari)}

Berdasarkan hasil sidik ragam untuk parameter umur muncul tunas tanaman pakis sayur dengan perlakuan media tanam dan pupuk NPK 16:16:16 menunjukkan bahwa interaksi kedua perlakuantidak memberikan pengaruh nyata terhadap umur muncul tunas tanaman pakis sayur. Rerata umur muncul tunas dapat dilihat pada tabel 1 .

Tabel 1 menunjukkan bahwa tidak ada pengaruh kedua perlakuan tersebut. Rata-rata umur muncul tunas tanaman pakis sayur berkisar antara 3,17 - 4,33 hari setelah tanam. Hal ini mengindikasikan bahwa munculnya tunas tanaman pakis sayur secara umum tidak dipengaruhi oleh kondisi media tanam dan juga nutrisi yang terkandung di dalam media tersebut. Sifat genetik dari induk tanaman pakis sayur diduga kuat mempengaruhi umur munculnya tunas tersebut. Secara hukum hereditas, pertumbuhan tanaman baik bentuk dan ukuran tubuhnya akan menurun pada anaknya. Sifat menurun merupakan gen yang terdapat pada setiap kromosom di dalam inti sel jaringan penyusun organ tubuh tumbuhan (Elrod dan Stanfield, 2007).

Tabel 1. Rerata umur muncul tunas pakis sayur dengan perlakuan media tanam dan pupuk NPK 16:16:16 (HST)

\begin{tabular}{|c|c|c|c|c|c|}
\hline \multirow{2}{*}{ Media Tanam } & \multicolumn{4}{|c|}{ Pupuk NPK 16:16:16 (g) } & \multirow[t]{2}{*}{ Rerata } \\
\hline & $0(\mathrm{~N} 0)$ & $0,3(\mathrm{~N} 1)$ & $0,6(\mathrm{~N} 2)$ & $0,9(\mathrm{~N} 3)$ & \\
\hline Gambut (M1 & 3,67 & 3,50 & 3,83 & 4,33 & 3,83 \\
\hline Mineral (M2) & 3,33 & 3,67 & 3,83 & 4,00 & 3,71 \\
\hline Kombinasi 1:1 (M3) & 3,67 & 4,00 & 4,33 & 3,17 & 3,79 \\
\hline Rerata & 3,56 & 3,72 & 4,00 & 3,83 & \\
\hline
\end{tabular}


Faktor utama dosis pupuk NPK 16:16:16 dan media tanam tidak berpengaruh terhadap umur muncul tunas dikarenakan saat muncul tunas, tanaman masih menggunakan cadangan makanan yang terdapat pada akar dan batang tanaman pakis. Cadangan makanan tersebut digunakan oleh tanaman sebagai bahan baku sintesis energi sebelum tanaman tersebut mampu berfotosintesis. (Burnie, 2010).

Faktor lain yang mempengaruhi pertumbuhan tunas tanaman pakis sayur adalah ketersedian air yang cukup. Tersedianya air tersebut menyebabkan proses katabolisme nutrisi yang terdapat pada tanaman pakis berjalan baik. Hal ini didukung oleh data curah hujan oleh Badan Meteorologi, Klimatologi dan Geofisika (BMKG) Kota Pekanbaru yang menunjukkan bahwa selama periode penelitian

\section{Tinggi Tanaman $(\mathrm{cm})$}

Berdasarkan hasil sidik ragam untuk parameter tinggi tanaman pakis sayur dengan perlakuan media tanam dan pupuk NPK 16:16:16 menunjukkan bahwa interaksi kedua perlakuan tidak memberikan pengaruh nyata terhadap tinggi tanaman pakis sayur begitu juga dengan pengaruh utama pupuk NPK 16:16:16. Sedangkan pengaruh utama media tanam memberikan pengaruh nyata terhadaptinggi tanaman. Rerata tinggi tanaman setelah diuji BNJ pada taraf 5\% dapat dilihat pada Tabel 2. akhir Bulan Maret sampai dengan awal Juli rata-rata curah hujan di Pekanbaru tergolong tinggi yaitu sebesar 220,86 $\mathrm{mm}$ dengan intensitas rata-rata 15,8 hari setiap bulannya.

Penggunaan shading net juga membuat kondisi media dan lingkungannya mengikuti habitat asalnya. Hal ini yang membantu pertumbuhan tunas tanaman pakis sayur sehingga perlakuan NPK 16:16:16 dan media tanam yang diberikan tidak memberikan respon yang positif pada tanaman tersebut. Hal ini sesuai dengan pernyataan Felania (2017) bahwa kondisi media dan lingkungan yang sesuai dapat mempengaruhi proses metabolisme selsel tanaman sehingga pertumbuhannya menjadi lebih baik.

Data pada tabel 2 telah ditransformasi, ini dikarenakan persentase koefisien keragamannya diatas $20 \%$. Besarnya persentase tersebut diduga akibat sumber bibit yang diambil tidak seragam.Dari data tersebut menunjukkan bahwa rerata tinggi tanaman pakis sayur tertinggi diperoleh pada perlakuan media kombinasi tanah gambut dan mineral 1:1 (M3) yaitu sebesar 7,88 cm dan tidak berbeda nyata dengan perlakuan media tanah mineral (M2) yaitu 7,55 $\mathrm{cm}$ namun berbeda nyata dengan perlakuan media tanah gambut (M1) sebesar 5,49 cm.

Tabel 2. Rerata tinggi tanaman pakis sayur dengan perlakuan media tanam dan pupuk NPK 16:16:16 (HST) telah ditransformasi $\sqrt{x}(\mathrm{~cm})$

\begin{tabular}{|c|c|c|c|c|c|}
\hline \multirow{2}{*}{ Media Tanam } & \multicolumn{4}{|c|}{ Pupuk NPK 16:16:16 (g) } & \multirow[t]{2}{*}{ Rerata } \\
\hline & 0 (N0) & 0,3 (N1) & $0,6(\mathrm{~N} 2)$ & 0,9 (N3) & \\
\hline \multirow[t]{2}{*}{ Gambut (M1) } & 5,52 & 5,73 & 5,50 & 5,19 & \multirow[t]{2}{*}{$5,49 \mathrm{~b}$} \\
\hline & $(30,75)$ & $(33,92)$ & $(30,58)$ & $(27,08)$ & \\
\hline \multirow[t]{2}{*}{ Mineral (M2) } & 7,68 & 7,79 & 7,33 & 7,42 & \multirow[t]{2}{*}{$7,55 \mathrm{a}$} \\
\hline & $(59,00)$ & $(60,75)$ & $(54,17)$ & $(55,42)$ & \\
\hline \multirow[t]{2}{*}{ Kombinasi 1:1 (M3) } & 7,53 & 7,36 & 8,22 & 8,41 & \multirow[t]{2}{*}{$7,88 \mathrm{a}$} \\
\hline & $(56,83)$ & $(54,75)$ & $(67,75)$ & $(70,75)$ & \\
\hline Rerata & 6.91 & 6.96 & 7.02 & 7,01 & \\
\hline $9,30 \%$ & \multicolumn{5}{|c|}{$\mathrm{BNJ} \mathrm{M}=0,66 \%$} \\
\hline
\end{tabular}

Angka-angka pada kolom yang diikuti oleh huruf kecil yang sama tidak berbeda nyata menurut uji lanjut BNJ pada taraf 5\%. Angka didalam kurung menunjukkan data asli.

Pertumbuhan dan perkembangan tanaman bergantung terhadap sifat-sifat yang dimiliki medianya. Media tanam yang sesuai akan mendukung pertumbuhan dan menghasilkan tanaman yang lebih baik. Hal ini seperti yang dijelaskan oleh Kusmawardana (2008) bahwa media tanam yang baik harus mampu menunjang metabolisme sel-sel organ tanaman sesuai dengan peranannya dalam pertumbuhan tanaman. 
Kombinasi antara tanah gambut dan tanah mineral menunjukkan respon yang positif terhadap tinggi tanaman pakis sayur. Media tanam yang baik akan mendukung proses penyerapan unsur hara dan juga air oleh akar yang diperlukan untuk pertumbuhan tanaman. Di dalam penelitiannya, Hanibal (2007) telah menjelaskan bahwa tanah gambut memiliki kandungan bahan organik yang tinggi sehingga dapat memperbaiki sifat fisika dan juga kimia dari tanah mineral dengan cara merangsang granulasi, meningkatkan porositas tanah, daya ikat air dan juga mampu merubah struktur tanah agar lebih remah dan gembur.

Pada tabel 2 dapat dilihat bahwa media tanah gambut (M1) memberikan tinggi tanaman pakis sayur terendah. Hal ini dikarenakan $\mathrm{pH}$ tanah pada media tanah gambut rendah sehingga ketersediaan unsur hara yang diperlukan oleh tanaman tidak tersedia akibat penyerapan unsur hara terhambat. Hal ini seperti yang telah dijelaskan Irwanto (2017), bahwa tanah gambut memiliki kekurangan yaitu miskin unsur hara, kadar $\mathrm{pH}$ yang rendah juga mudah teroksidasi.

\section{Jumlah Daun Muda (helai)}

Berdasarkan hasil sidik ragam untuk parameter jumlah daun muda pakis sayur dengan perlakuan media tanam dan pupuk NPK 16:16:16 menunjukkan bahwa baik pengaruh interaksi maupun pengaruh utama dari kedua perlakuan (Media tanam dan pupuk NPK 16:16:16) memberikan pengaruh nyata terhadap jumlah daun muda pakis sayur. Rerata jumlah daun muda setelah diuji lanjut BNJ pada taraf 5\% disajikan pada Tabel 3.

Data pada tabel 3 menunjukkan bahwa secara pengaruh interaksi maupun pengaruh utama perlakuan media tanam dan pupuk NPK 16:16:16 memberikan pengaruh yang berbeda nyata terhadap jumlah daun muda tanaman pakis sayur. Secara interaksi, rata-rata jumlah daun tertinggi diperoleh dari tanaman yang diberi perlakuan media kombinasi tanah gambut dan mineral 1:1 dan 0,6 g/tanaman pupuk NPK 16:16:16 (M3N2) yaitu sebanyak 2,08 helai. Sedangkan rata-rata jumlah daun terendah diperoleh dari tanaman yang diberi perlakuan media tanah gambut dan 0 g/tanaman pupuk NPK 16:16:16 (M1N0) yaitu 1,28 helai.

Kombinasi antara tanah gambut dan tanah mineral terbukti memberikan pengaruh yang positif terhadap pertumbuhan tanaman ini disebabkan oleh interaksi kedua sifat fisika maupun kimia dari tanah tersebut (Sibagariang, dkk., 2017).

Tabel 3. Rerata jumlah daun muda pakis sayur dengan perlakuan media tanam dan pupuk NPK 16:16:16 (HST) telah ditransformasi setelah ditransformasi $\sqrt{x+1}$ (helai)

\begin{tabular}{crrrrr}
\hline \multirow{2}{*}{ Media Tanam } & \multicolumn{4}{c}{ Pupuk NPK 16:16:16 (g) } & \multirow{2}{*}{ Rerata } \\
\cline { 2 - 5 } & $0(\mathrm{~N} 0)$ & $0,3(\mathrm{~N} 1)$ & $0,6(\mathrm{~N} 2)$ & $0,9(\mathrm{~N} 3)$ & \\
\hline Gambut (M1) & $1,28 \mathrm{~d}$ & $1,73 \mathrm{a}-\mathrm{d}$ & $1,44 \mathrm{~cd}$ & $1,62 \mathrm{a}-\mathrm{d}$ & $1,52 \mathrm{~b}$ \\
& $(0,67)$ & $(2,00)$ & $(1,17)$ & $(1,67)$ & \\
\hline Mineral (M2) & $1,91 \mathrm{a}-\mathrm{d}$ & $1,91 \mathrm{ab}$ & $1,87 \mathrm{abc}$ & $1,87 \mathrm{abc}$ & $1,80 \mathrm{a}$ \\
& $(1,50)$ & $(2,67)$ & $(2,50)$ & $(2,50)$ & \\
\hline Kombinasi 1:1 (M3) & $1,73 \mathrm{a}-\mathrm{d}$ & $1,96 \mathrm{ab}$ & $2,08 \mathrm{a}$ & $1,52 \mathrm{bcd}$ & $1,82 \mathrm{a}$ \\
& $(2,00)$ & $(2,83)$ & $(3,33)$ & $(1,33)$ & \\
\hline Rerata & $1,57 \mathrm{~b}$ & $1,87 \mathrm{a}$ & \multicolumn{1}{c}{$1,80 \mathrm{a}$} & $1,67 \mathrm{ab}$ \\
\hline KK= 9.40\% & BNJ M=0,16 & BNJ N=0,21 & BNJ MN=0,47 & & \\
\hline
\end{tabular}

Angka-angka pada kolom yang diikuti oleh huruf kecil yang sama tidak berbeda nyata menurut uji lanjut BNJ pada taraf $5 \%$. Angka didalam kurung menunjukkan data asli.

Media tanam merupakan komponen yang sangat penting dalam budidaya tanaman. Selain sebagai penopang akar tanaman, media tanam juga berfungsi sebagai tempat tersimpannya nutrisi, air dan tempat hidupnya komponen biotik yang mampu membantu pertumbuhan dan perkembangan tanaman. Mumpuni (2015) menyatakan bahwa pertumbuhan dan perkembangan dari tanaman pakis sayur di habitat aslinya didukung oleh tanah yang banyak mengandung bahan organik.

Kombinasi antara media tanam dan pupuk NPK 16:16:16 dapat memperbaiki sifat fisika dan kimia tanah. Kombinasi tersebut mampu membantu proses pengambilan unsur 
hara dan air oleh akar. Seperti yang dijelaskan oleh Rosmarkam dan Nasih (2011), bahwa peranan akar sangat bergantung kepada kualitas medianya agar dapat membantu dalam proses metabolisme tanaman dalam menunjang pertumbuhan.

Pertumbuhan dan perkembangan tanaman sangat dipengaruhi oleh ketersedian unsur hara esensial di dalam tanah.Jumlah daun menjadi salah satu satu faktor untuk melihat bagaimana laju pertumbuhan suatu tanaman. daun merupakan organ yang sangat penting dalam metabolisme tanaman, karena di daun tempat terjadinya proses fotosintesis yaitu proses sintesis glukosa dengan bantuan cahaya matahari dan air. Hasibuan (2016) menegaskan bahwa semakin banyak jumlah daun tanaman, maka pertumbuhan tanaman juga semakin baik.

Candra dan Sumjulia (2017) menjelaskan bahwa, nitrogen di dalam pupuk NPK 16:16:16 berperan penting dalam partumbuhan vegetatif tanaman terutama daun muda. Nitrogen merupakan salah satu unsur makro yang paling berperan dalam pertumbuhan vegetatif tanaman. Penjelasan ini sesuai dengan hasil penelitian yang menunjukkan bahwa media tanam dan pupuk NPK 16:16:16 mempengaruhi rata-rata jumlah daun muda pakis sayur.

\section{Berat Basah Ekonomis (g)}

Setelah dilakukan penimbangan terhadap berat basah daun muda tanaman pakis sayur dan kemudian hasilnya dianalisis sidik ragam menunjukkan bahwa secara interaksi perlakuan media tanam dan pupuk NPK 16:16:16 tidak menunjukkan pengaruh nyata terhadap berat basah ekonomis pakis sayur. Sedangkan untuk pengaruh utama dari kedua perlakuan memberikan pengaruh nyata terhadap berat basah daun muda pakis sayur. Rerata berat basah ekonomis tanaman pakis sayur setelah diuji lanjut BNJ pada taraf 5\% disajikan pada Tabel 4.

Tabel 4. Rerata berat basah ekonomis pakis sayur dengan perlakuan media tanam dan pupuk NPK 16:16:16 (HST) telah ditransformasi setelah ditransformasi $\sqrt{x+1}$ (helai)

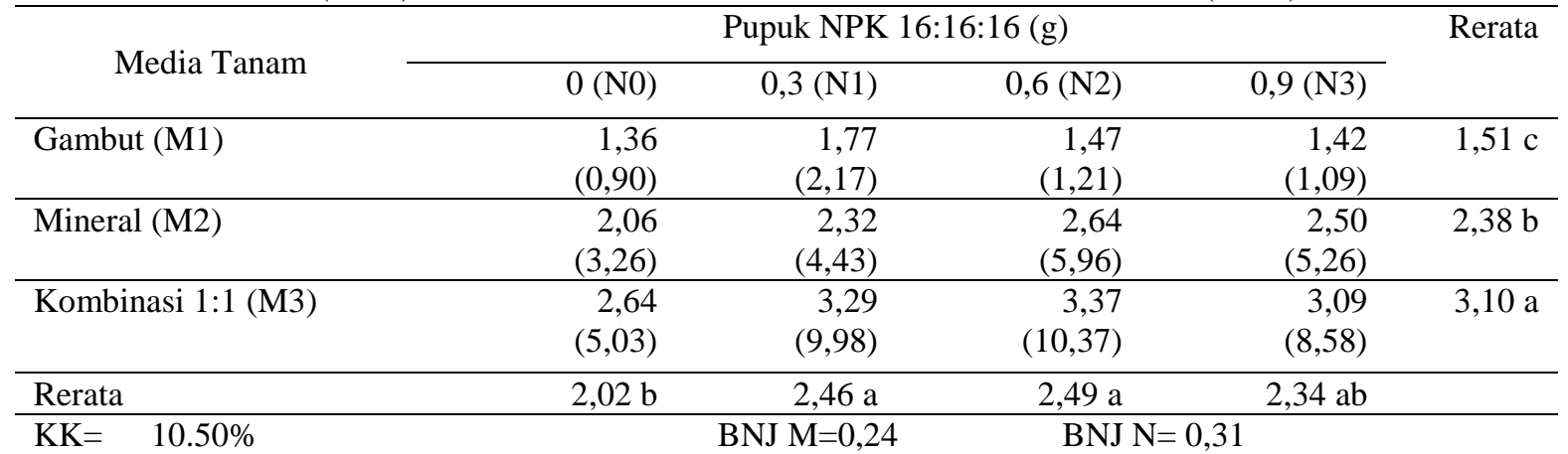

Angka-angka pada kolom yang diikuti oleh huruf kecil yang sama tidak berbeda nyata menurut uji lanjut BNJ pada taraf $5 \%$. Angka didalam kurung menunjukkan data asli.

Data pada tabel 4 menunjukkan bahwa perlakuan media tanam dan pupuk NPK 16:16:16 meningkatkan rata-rata berat basah ekonomis daun muda tanaman pakis sayur dengan hasil tertinggi yaitu $3,10 \mathrm{~g}$ pada perlakuan media tanahgambut dan mineral 1:1 (M3) dan berbeda nyata dengan media tanah gambut (M1) dengan hasil 1,51 g.

Perlakuan pupuk NPK 16:16:16 secara utama berpengaruh nyata meningkatkan berat basah ekonomis tanaman pakis sayur. Rata-rata berat tertinggi diperoleh oleh tanaman yang diberi perlakuan 0,6 g pupuk NPK 16:16:16

(N2) yaitu sebesar 2,49 g, namun tidak berbeda nyata dengan pemberian $0,3 \mathrm{~g}$ pupuk NPK 16:16:16 (N1) yaitu sebesar 2,46 g dan rata-rata berat ekonomis terendah diperoleh oleh tanaman yang diberi perlakuan $0 \mathrm{~g}$ pupuk NPK 16:16:16 (N0) yaitu sebesar 2,02 g.

Berat basah tanaman merupakan komposisi unsur hara dan juga kandungan air yang terdapat pada bagian atau keseluruhan dari tanaman tersebut (Putra, 2016). Berat 
tanaman menjadi tolak ukur dalam melihat sejauh mana proses metabolisme tanaman berlangsung, seperti proses fotosintesis tanaman dan juga efektivitas penyerapan unsur hara dan air dari dalam tanah, kondisi media yang sesuai dan juga tersedianya unsur hara inilah yang mempengaruhi berat basah tanaman.

Media kombinasi tanah gambut dan mineral 1:1 (M3) menghasilkan berat basah daun muda pakis sayur tertinggi. Hal ini menunjukkan bahwa pada media tersebut mampu mendukung pertumbuhan tanaman terutama terhadap akar dalam penyerapan air dan juga unsur hara. Amir (2016) menjelaskan bahwa perkembangan akar sangat bergantung pada kondisi media tanam. Semakin baik media tanam, maka semakin baik pula kinerja dari akar untuk menyerap air dan juga unsur hara.

Selain media tanam, pemberian pupuk NPK 16:16:16 pada tanaman secara utama memberikan pengaruh yang nyata. Sutedjo (2001) menyatakan bahwa pemberian nutrisi tambahan (pupuk) pada media tanam dapat membantu menyediakan bahan yang digunakan oleh tanaman untuk mensintesis karbohidrat dan juga energi. Unsur Kalium (K) pada pupuk NPK 16:16:16 berperan dalam membuka dan menutupnya stomata melalui peningkatan aktivitas turgor. Selain itu, unsur $\mathrm{K}$ memacu translokasi asimilat dari source ke sinkyang menjaga aliran unsur hara dan air. Hal ini yang menyebabkan pertumbuhan tanaman pakis sayur menjadi lebih baik.

\section{Berat Kering (gram)}

Setelah dilakukan penimbangan terhadap berat kering daun muda tanaman pakis sayur dan kemudian hasilnya dianalisis sidik ragam menunjukkan bahwa pengaruh utama dari media tanam dan pupuk NPK 16:16:16 berpengaruh nyata terhadap berat kering daun muda pakis sayur, sedangkan secara interaksi perlakuan media tanam dan pupuk NPK 16:16:16 menunjukkan pengaruh tidak nyata terhadap berat kering daun muda pakis sayur. Rerata berat kering daun muda pakis sayur setelah diuji lanjut BNJ pada taraf $5 \%$ disajikan pada tabel 5.

Tabel 5. Rerata berat kering pakis sayur dengan perlakuan media tanam dan pupuk NPK 16:16:16 (HST) telah ditransformasi setelah ditransformasi $\sqrt{x+1}$ (gram)

\begin{tabular}{|c|c|c|c|c|c|}
\hline \multirow{2}{*}{ Media Tanam } & \multicolumn{4}{|c|}{ Pupuk NPK 16:16:16 (g) } & \multirow{2}{*}{ Rerata } \\
\hline & $0(\mathrm{~N} 0)$ & $0,3(\mathrm{~N} 1)$ & $0,6(\mathrm{~N} 2)$ & $0,9(\mathrm{~N} 3)$ & \\
\hline \multirow[t]{2}{*}{ Gambut (M1) } & 1,04 & 1,14 & 1,08 & 1,08 & \multirow[t]{2}{*}{$1,08 \mathrm{c}$} \\
\hline & $(0,08)$ & $(0,30)$ & $(0,17)$ & $(0,17)$ & \\
\hline \multirow[t]{2}{*}{ Mineral (M2) } & 1,23 & 1,36 & 1,37 & 1,35 & \multirow[t]{2}{*}{$1,33 \mathrm{~b}$} \\
\hline & $(0,53)$ & $(0,78)$ & $(0,89)$ & $(0,83)$ & \\
\hline \multirow[t]{2}{*}{ Kombinasi 1:1 (M3) } & 1,35 & 1,51 & 1,57 & 1,51 & \multirow[t]{2}{*}{$1,48 \mathrm{a}$} \\
\hline & $(0,82)$ & $(1,29)$ & $(1,47)$ & $(1,27)$ & \\
\hline Rerata & $1,21 \mathrm{~b}$ & $1,34 \mathrm{a}$ & $1,34 \mathrm{a}$ & $1,31 \mathrm{ab}$ & \\
\hline $7,10 \%$ & & BNJ $M=0,09$ & $\mathrm{BNJ} \mathrm{N}=$ & & \\
\hline
\end{tabular}

Angka-angka pada kolom yang diikuti oleh huruf kecil yang sama tidak berbeda nyata menurut uji lanjut BNJ pada taraf $5 \%$. Angka didalam kurung menunjukkan data asli.

Pengaruh utama media tanam memberikan pengaruh terbaik terhadap ratarata berat kering daun muda tanaman pakis sayur pada perlakuan kombinasi tanah gambut dan mineral 1:1 (M3) yaitu sebesar 1,48 g. Berat kering daun muda tanaman pakis sayur paling rendah adalah tanaman yang diberi perlakuan tanah gambut (M1) yaitu sebesar $1,08 \mathrm{~g}$.

Pengaruh utama yang berbeda nyata terhadap rata-rata berat kering daun muda tanaman pakis sayur juga ditunjukkan pada perlakuan pemberian pupuk NPK 16:16:16. Rata-rata berat kering daun muda tanaman pakis sayur tertinggi diperoleh dari tanaman yang diberi perlakuan $0,6 \mathrm{~g}$ pupuk NPK 16:16:16 (N2) yaitu sebesar 1,34 g dan yang paling rendah adalah tanaman yang diberi perlakuan $0 \mathrm{~g}$ pupuk NPK 16:16:16 (N0) yaitu sebesar 1,21 g. Hasil tersebut menunjukkan bahwa pemberian pupuk NPK 16:16:16 mampu mempengaruhi berat kering daun muda tanaman pakis sayur. 
Hasibuan (2016) mendefenisikan berat kering tanaman adalah hasil penimbunan hasil bersih dari asimilasi $\mathrm{CO}_{2}$ yang dilakukan selama pertumbuhan dan perkembangan tanaman. Berat kering juga dapat dihitung dari salah satu bagian organ saja seperti daun, akar dan juga batang. Berat kering diperoleh dengan cara menghilangkan kadar air yang terdapat pada bagian tersebut.

Berat kering dapat menjadi acuan dalam melihat sejauh mana pertumbuhan dan perkembangan suatu tanaman berlangsung. Menurut Akasiska (2014), menyatakan bahwa apabila unsur hara yang dibutuhkan pada fotosintesis jumlahnya terbatas maka unsur hara tersebut akan ditranslokasikan dari daun tua ke daun muda sehingga laju fotosintesis pada daun tua akan berkurang. Sedangkan Putra (2016), menyatakan bahwa tinggi dan rendahnya bahan kering tanaman tergantung pada sedikitnya serapan unsur hara yang berlangsung dalam proses pertumbuhan.

Media kombinasi tanah gambut dan mineral 1:1 (M3) memberikan hasil tertinggi dibandingkan dari media lainnya. Kombinasi media ini memiliki sifat yang mampu menunjang pertumbuhan tanaman yaitu drainase yang baik dan lembab. Hal ini senada dengan penjelasan Augustien dan Hadi (2006) bahwa media tanam yang baik yaitu media yang memiliki sifat fisik lembab, berpori dan memiliki draenase yang baik. Media yang baik akan membantu organ akar tanaman dapat bekerja dengan baik. Peningkatan kinerja dari akar akan mempengaruhi proses fotosintesis tanaman menjadi lebih maksimal sehingga menghasilkan fotosintat yang maksimal pula.

Rata-rata berat kering daun muda pada tanaman yang diberi perlakuan media tanah gambut (M1) menjadi yang paling rendah jika dibandingkan dengan perlakuan lainnya. Hal ini disebabkan oleh sifat fisika dan kimia dari tanah gambut yang memiliki banyak kekurangan. Tanah gambut memiliki sifat yang asam dikarenakan banyaknya terdapat ion-ion $\mathrm{H}^{+}, \mathrm{Al}^{3+}$ dan $\mathrm{Fe}^{3+}$. Ion-ion ini dapat menghambat penyerapan unsur hara essensial tanaman. Dengan begitu kapasitas tukar kation (KTK) pada tanah gambut juga sangat kecil (Nurhayati, 2008).

Hasil penelitian menunjukkan bahwa perbedaan media dan juga pupuk NPK mampu memberikan hasil rata-rata berat kering daun muda yang berbeda pula. Daun muda pada suatu tannaman merupakan daun yang masih bersifat meristematik sehingga kadar airnya juga tinggi. Jumin (2005) menjelaskan bahwa hasil fotosintesis berkaitan erat dengan proses fisiologi yang terjadi pada daun, dalam arti lain seandainya proses fisiologi pada daun tidak maksimal, maka akan menurunkan hasil bersih fotosintesis yang dapat diukur melalui berat kering.

Perlakuan pupuk NPK 16:16:16 secara utama memberikan pengaruh nyata terhadap berat kering daun muda pakis sayur dengan perlakuan terbaik yaitu $0,3 \mathrm{~g}$ (N1). Nitrogen merupakan penyusun setiap sel hidup, karena terdapat pada seluruh bagian tanaman. Fosfor juga penyusun setiap sel hidup. Fosfor sangat berperan aktif dalam mentransfer energi didalam sel, mengubah karbohidrat,dan meningkatkan efesiensi kerja kloroplas (Augustien dan Hadi, 2006). Hal inilah yang mempengaruhi hasil berat kering daun muda tanaman pakis sayur melalui proses fotosintesis (fotosintat).

Perlakuan 0,6 g pupuk NPK 16:16:16 (N2) memberikan hasil berat kering yang lebih tinggi jika dibandingkan dengan perlakuan 0,9 $g$ pupuk NPK 16:16:16 (N3). Hal ini menjelaskan bahwa titik maksimal penumpukan hasil dari fotosintesis tanaman (fotosintat) adalah 0,6 g pupuk NPK 16:16:16 (N2). Pemberian pupuk NPK 16:16:16 diatas dosis maksimalnya dapat menyebabkan pertumbuhan tanaman pakis sayur terhambat (Kuruseng dan Hamzah. 2011).

\section{KESIMPULAN}

Berdasarkan penelitian yang telah dilakukan, maka dapat diambil kesimpulan bahwa :

1. Interaksi media tanam dan pupuk NPK 16:16:16 memberikan pengaruh nyata terhadap jumlah daun muda dengan perlakuan terbaiknya adalah media tanam kombinasi tanah gambut dan mineral 1:1 dan 0,6 g pupuk NPK 16:16:16 (M3N2).

2. Pengaruh utama media tanam nyata terhadap parameter tinggi tanaman, jumlah daun muda, berat basah ekonomis, dan berat kering. Perlakuan terbaik terdapat pada media tanam media kombinasi tanah gambut dan mineral 1:1 (M3). 
3. Pengaruh utama pupuk NPK 16:16:16 nyata terhadap jumlah daun muda, berat basah ekonomis dan berat kering dengan perlakuan terbaik $0,3 \mathrm{~g}(\mathrm{~N} 1)$.

\section{DAFTAR PUSTAKA}

Akasiska, R. 2014. Pengaruh konsentrasi nutrisi dan media tanam terhadap pertumbuhan dan hasil sawi pakcoy (Brassica parachinensis) Sistem Hidroponik Vertikultur. Fakultas Pertanian. Universitas Slamet Riyadi. Jurnal Inovasi Pertanian. 13 (2): 46-61

Amir, B. 2016. Pengaruh perakaran terhadap penyerapan nutrisi dan sifat fisiologis pada tanaman tomat(Lycopersicum esculentum). Fakultas Pertanian. Universitas Cokroaminoto Palopo.

Augustien, N. dan Hadi S. 2016. Peranan berbagai komposisi media tanam organik terhadap tanaman sawi (Brassica juncea L.) di polibag. Prodi Agroteknologi. Fakultas Pertanian. UPN "Veteran" Jatim.

Burnie, D. 2010. Eyewitness Plant. Jakarta : Penerbit Erlangga

Candra, M. K dan Sumjulia. 2017. Pengaruh komposisi media tanam dan dosis NPK terhadap pertumbuhan stek kantong semar (Nepenthes ampullaria Jack). Fakultas Pertanian. Universitas Kapuas Sintang. PIPER. 13 (24): 27-38

De Winter, W.P. and V.B. Amoroso. 2003. Plant Resources of South-East Asia No. 15(2). Cryptograms: Ferns and Fern Allies. Prosea Foundation, Bogor, Indonesia. pp. 13-46.

Elrod S.L dan W.D. Stanfield. 2007. Genetika. Jakarta: Penerbit Erlangga

Felania, C. 2017. Pengaruh ketersediaan air terhadap pertumbuhan kacang hijau (Phaceolus radiatus). Prosiding Seminar Nasional Pendidikan Biologi dan Biologi Jurusan Pendidikan Biologi. FMIPA. Universitas Negeri Yogyakarta.

Hanibal. 2007. Pengaruh kombinasi tanah gambut dan tanah mineral sebagai media pertumbuhan bibit kelapa sawit (Elaeis guineensis Jacq.) di pembibitan utama. Fakultas Pertanian. Universitas Jambi

Hasibuan, R.I. 2016. Intensitas penyiangan gulma dan pengaruhnya terhadap perkembangan biji dari 4 varietas kacang hijau (Vigna radiata. L). Fakultas Pertanian. Universitas Islam Riau

Irwanto, D. 2017. Uji pemberian pupuk bioorganik plus (POMI) terhadap pertumbuhan dan produksi tanaman bawang merah (Allium ascalonicum, L) pada campuran media tanah gambut dan podzolik merah kuning. Fakultas Pertanian. Universitas Islam Riau.

Jumin, H. B. 2005. Dasar-Dasar Agronomi. Edisi Revisi. P. T. Raja Grafindo Persada. Jakarta.

Kusmawardana, A. 2008. Pengaruh konsentrasi rootone $\mathrm{F}$ dan jenis media tanam konsentrasi hormon gibbralin (GA3) dan komposisi media tumbuh terhadap pertumbuhan kayu putih (M.caputri linn). Thesis University of Muhamadiah Malang.

Mumpuni, K.E., H. Susilo. dan F. Rochman. 2014. Potensi tumbuhan lokal sebagai sumber belajar biologi. Pascasarjana Pendidikan Biologi. Universitas Negeri Malang.

Nurhayati. 2008. Tanggap tanaman kedelai di tanah gambut terhadap pemberian beberapa jenis bahan perbaikan tanah. Tesis. Sekolah Pasca Sarjana. Universitas Sumatera Utara.

Putra, D.E., H. Yetty dan S.I. Saputra. 2012. Pengaruh sisa dolomit dan pupuk NPK terhadap pertumbuhan dan produksi tanaman caisim (Brassica chinensis) di lahan gambut. Jurusan Agroteknologi Fakultas Pertanian. Universitas Riau.

Putrasamedja, S. 2005. Eksplorasi dan koleksi sayuran indigenous di Kabupaten Karawang, Purwakarta, dan Subang. Bul. Plasma Nutfah 11 (1) : 16-20.

Rosmarkam. A. dan N. Widya Yuwono. 2011. Ilmu Kesuburan Tanah. Yogyakarta. Kanisius.

Sibagariang, D.A, Wawan dan Husna Y. 2017. Pengaruh pemberian tanah mineral dan aerasi pada tanah gambut yang disawahkan terhadap pertumbuhan dan produksi tanaman padi (Oryza sativa. L). Fakultas Pertanian. Universitas Islam Riau.

Sutedjo, M.M. 2001. Pupuk dan Cara Pemupukan. PT. Rhineka Cipta. Jakarta. 
